\begin{tabular}{|c|c|c|}
\hline$A$ & $\begin{array}{c}\text { International Journal of Current Research } \\
\text { and Academic Review }\end{array}$ & \\
\hline $\begin{array}{l}\text { EXCELLENT } \\
\text { PUBLISHERS }\end{array}$ & $\begin{array}{c}\text { ISSN: 2347-3215 (Online) } \because, \text { Volume } 5:, ; \text { Number } 4 \text { (April-2017) } \\
\text { Journal homepage: http://www.ijcrar.com }\end{array}$ & \\
\hline
\end{tabular}

doi: https://doi.org/10.20546/ijcrar.2017.504.007

\title{
Indian Foreign Trade on Natural Cellulosic Jute Fibre Products
}

\author{
Satya Narayan Bag ${ }^{*}$ \\ Principal, AMS College of Polytechnic, Rangapur, Barrackpur, 24 Pgs (N), West Bengal, India \\ *Corresponding author:
}

\begin{abstract}
Jute is Natural Biodegradable Fibre and has great Economic value next to Cotton. Fibre Contains $\alpha$ and $\beta$ Cellulose with Lignin, a Complex compound. Jute mainly grows in highly rainfalls areas, like India, Bangladesh, Nepal, and Myanmar. A large number of people in such countries are now involved from Cultivation of Fibre to Finished goods production and Marketing process. World Jute goods Consumption are now increasing due to Eco friendly Nature of Fibre. India is the Largest Manufacturer and Exporter of Jute goods. Jute is not only used as Packaging Materials, but also used for various purposes. For example, Wall Coverings, Carpets, Gift Items, Geo Textiles, Hands \& Shopping Bags, Handicrafts Jute products and many. Analysis has been shown that such products have great demand in International Market. USA, UK, Australia, Arabian and South African countries are now leading buyers of such Indian Products. High prospects and great scope of Jute Industry has taken leading role for foreign currency earning and economic development of India. People of different corner of world are now realized that to keep the Environment Clean and Pollution free, Natural Jute Fibre products are now very urgent.
\end{abstract}

\section{Article Info}

Accepted: 04 April 2017

Available Online: 20 April 2017

\section{Keywords}

Cellulose, Exporter,

Manufacturer,

Jute Products,

Eco-Friendly.

\section{Introduction}

The Jute Industry occupies an important place in the national economy of India. It is one of the major industries in the eastern region; particularly in West Bengal. Jute the golden fiber meets all the standards for 'safe' packaging in view of being a natural, renewable, biodegradable and eco friendly products. It is estimated that the Jute industry provides direct employment of 0.37 million workers in organized mills and in diversified units including tertiary sector and allied activities and support the livelihood of around 4.0 million farm families. In addition there are a large number of persons engaged in the trade of Jute. In terms of Jute goods, India is the leading producing countries in the world, accounting for about two-third of total world production followed by Bangladesh accounting for almost one third. Jute is also cheap and capable to produce widest range of consumer goods as per the customer specification. A large number of small and tiny units produce consumer items of different varieties and uses. These items are not only durable attractive from aesthetic sense. Diversified Jute products have been developed and have emerged as life style products. The prominent items in the export include floor coverings, hand and shopping bags and decorative fabrics.USA and some European countries are the major markets for Indian Jute DJPS.

\section{Research Methodology}

Export data of Different Jute goods were studied from various journals, Web sites of Government bodies, 
publication on various web sites etc. The data are therefore tabulated and analyzed for Export value of Jute goods and Present Status of such products in International Markets. Different Government initiatives are taken for enhancement of such products export and suggestive measures for potential improvement of such Natural Biodegradable products in International Markets..

\section{Literature review}

Rahim Akter ${ }^{1}$ (June 2015), stated in her research findings that the production of diversified jute goods in Bangladesh has got a momentum because of environmental awareness and rise of green business among consumers in worldwide. Bangladesh's traditional jute goods production shifted to more value added products. The country is failed to diversify its market base compare to increasing demand in worldwide. The paper suggests some recommendation for the exporters.

MD Mohiuddin ${ }^{2}$ (Feb 2015), stated in his research findings that agro-climatic environment made Bangladesh a natural home for producing the best quality jute in the world. It has played a significant role in the economy and history of Bangladesh. Even today the decaying jute sector accounts for the third highest foreign currency earner after readymade garments and frozen foods in Bangladesh. Bangladesh controls $62 \%$ share of the total jute goods markets of the world. Bangladesh is the only exporter of raw jute.

\section{Results and Discussion}

Table 01 explained the Jute goods imports features of Indian continent. Here Jute products indicate Jute Bags, Jute Twine, Jute Yarn and Jute cloth /CBC. India imported jute products from Bangladesh for domestic purpose. It is found that import of Jute products from Bangladesh during February 2016 increased by $8 \%$ in quantity and $52 \%$ in Value terms as compared to February 2015.

Table 02 and Figure 01 explained the Export of All Jute Goods to Top 12 countries in the year 2014-15. It is found that in the year 2014-15, USA was the leading importing Countries of all jute goods from India and UK was the $2^{\text {nd }}$ largest importer of all jute goods from India and the contribution of import of the two countries were $23 \%$ and $8 \%$ respectively. Apart from that Ghana,
Netherlands, Germany, Saudi Arab were importing Jute Goods from India.

Figure 02 represents the Export value of Hessian Fabric from India. The graph showed that gradually decreasing trend of hessian Cloth Export from June to November 2017.In the Month of June 2016 India exported Hessian cloth worth USD 6539187 of total quantity of 50053380 . United States was the largest buyer of Hessian cloth accounting for exports worth USD 1086869 during June 2016 followed by Saudi Arabia and Egypt which imported hessian cloth worth USD 714948 and USD 566869 respectively. On the other hand in the month November 2016, India Exported Hessian cloth worth USD 3986334 during November 2016 with total quantity of 111624640.in this month United States was the largest buyer of hessian cloth accounting for.

Exported worth USD 668918 during November 2016 followed by Saudi Arabia and Germany which imported hessian cloth worth USD 298039 and USD 257702 respectively

From the figure 03 it is found that in the year 2015-16, United States was the largest Buyers of hessian cloth import from India and value of contribution was $22.3 \%$ of the total export value on the same year. Germany and Saudi Arabia were the $2^{\text {nd }}$ and $3^{\text {rd }}$ largest importer of hessian cloth import from India and their contribution towards import of hessian Jute cloth were $6.9 \%$ and 5,7 $\%$ respectively. United Kingdom, Egypt and Australia were significant position towards hessian cloth import from India. From the discussion it is found that foreign buyers are environmental pollution conscious. They are more interested about Jute fabrics for various purposes due to Environmental pollution free utilization of such products

From the figure 04, it is found that Kolkata Sea accounted for $91.9 \%$ of exports followed by Vizac Sea and Chennai Sea which accounted for $3.5 \%$ and $2 \%$ of exports respectively.

Figure 05 indicates that Indian Export Value of jute bags has decreasing trend from the month June 2016 to November 2016.India exported Jute Bags worth USD 96442141 during June 2016 with total quantity of 107076633. Indonesia was the largest buyer of jute Bags on that time. Saudi Arabia and Ghana imported Jute bags worth USD 14940928 and USD 6156614 respectively. Indonesia imported 107076633 quantities of Jute bags. Whereas on the Month November 2016; India exported 
Jute bags worth USD 59401418 during November 2016 with total quantity of 56480040. Saudi Arabia was the largest buyer of Jute Bags on that month and was importing USD 15739105 during that time. Kuwait and Indonesia imported Jute Bags worth USD 5915963 and USD 5847431 respectively. Mundra, Kolkata Sea and Nhava Shiva Sea were the imported ports for exporting such products.

Table 0-1 explained the Export value of Jute goods from India over different years. It is found that yarn export value has been decreased by $3.79 \%$ from the year 200910 to 2014-15.it is due to lower demand in international Market of Jute twine. This lower demand has been observed by other exporting countries like Bangladesh, Nepal, China. Other products like Hessian fabrics, sacking bags and cloth and Diversified Jute products (JDPs) has been increased from the year 2009-10 to 2014-15.. Hessian export value has been increased by $141.66 \%$ from the given year, whereas sacking export has been increased by $167.15 \%$ and Jute Diversified products has been increased by $120.3 \%$ on the same period. From the figure 06, it is observed that export value in Rs/ Million of 4 different Jute goods over different years. It is found that Jute Diversified Products exports value were increasing from 2009-10 to 201415.and reached highest in the year 2014-15. Hessian Jute goods exports were the highest in value in comparison to other products like sacking, Yarn and JDPs Hessian Jute goods exports were highest on the year 2011-12 and thereafter gradually falls, on the other hand Sacking goods exports were highest on the year 201314.Fluctuations of Jute goods exports were due to the variation of demand of such products and rise of such Natural fibre products.

Table 04 explained the Export of Jute Diversified Products (JDPs) from India over different years. From the table 04, it is found that, Export of Floor Coverings has been increased by $77.96 \%$ from the year 2010-11 to 2014-15. On the other Hand \& Shopping Bags, Gift articles, Decorative Fabrics has been increased in export value of $99.20 \%, 77.07 \%$ and $332.40 \%$ respectively on the same period of observation. From the foregoing discussion, it is cleared that Jute the natural Fibre products has good demand in International Market.

Figure 7 Indicates that Hand and Shopping Bags and Floor coverings export value has been increasing from the year 2010-11 to 2014-15; as a result total export value of JDPs has been increasing simultaneously on the same year. This is proved that Indian Jute products demand has higher demand in foreign countries and people are more conscious about biodegradable Jute products, since it creates pollution free environment.

Figure 8 explained that, Floor Coverings and Hand \& Shopping Bags export value Contribution of Total JDPs Export were $47 \%$ and $49.5 \%$ respectively on the year 2014-15.Floor Coverings and Hand \& Shopping Bags are the major Jute diversified products exported to foreign countries. On the other hand, Decorative Fabrics, Gift Articles and Wall Hangings Export value contributions were $2.43 \%, 0.79 \%$ and $0.16 \%$ respectively of the year 2014-15.

Figure 10 explained the trend of export value from the Month of May 2016 to the Month of October 2016.It is found that the graph exhibits an increasing trend In the Month of May the export value of such product was 519675 USD, whereas in the month of October 2016, the value of Export was 770151 USD, so there was $48.19 \%$ increase in Export value from Indian continent. It is proved Jute laminated bags have good demand in International Market and Jute industry has good future. A large number of people are linked with this production process.

People of Foreign countries are now very much conscious about the use of such product of natural origin. The products of such areas are Laminated Jute Bags, Jute Shopping Bags laminated with handle \& japer. Jute shopping bags with LDPE laminated \& Jute Hand bags laminated.

Figure 11 explained that, Kolkata Sea is the largest port in India where $75.8 \%$ of total value of export of laminated jute bags in the year 2015016 and export value of 23981781 USD has been reported. Apart from this, Nihavas hava Sea 9.5\%, and Kolkata Air Cargo $4.2 \%$ of the export value share on the same period.. Major exporting countries are United Kingdom is the largest buyer of such product from India and its export value share was $40.1 \%$ of the Indian total export value in the year 2015-16..Other buyers are United States (22.3\%), Saudi Arabia (7.4\%), Germany (5.1\%), France (3.1\%), Australia $93.0 \%)$, Netherlands (2.1\%), Italy $91.9 \%)$ and Japan $(1.2 \%)$ of the Indian total export value of such products.

From the Figure 12, it is found that, Export value of Jute Geo textile in terms of USD has been increasing from January 2016 to October 2016 and export value was rising by $20.9 \%$ in the same year. In the Month of 
January 2016 Indian export value was 32607 USD where as in the month of October 2016 export value was 39439 USD was reported. Jute Geo textile has so many advantages. It is used for River Bank protection, soil erosion and control, various Civil Construction activities,

From the table 05, it is found that United States was the largest Buyers of Jute Geo textiles of Indian product and share of export was $97.7 \%$ of the total export value. Apart from US, Kenya, Australia and China were the buyers of such product of the year 2015-16.

Figure 13 explained that $95.7 \%$ of Export was taken place from Kolkata Sea, followed by Cochin Sea $4.2 \%$ and Kolkata Air cargo $0.1 \%$ contribution towards total exports value of Jute Geo Textiles from India.

Table 06 indicates the Export value of Indian Jute Shopping Bags of the Year 2015-16. It is observed that, United is the leading Buyer of such products and its share was $47.1 \%$ in the year 2015-16.United States and Australia were the $2^{\text {nd }}$ and $3^{\text {rd }}$ largest buyers of such products and their share were $17.7 \%$ and $6.8 \%$ respectively. From the table it is found that Jute shopping industry has great market opportunities in foreign countries and industry has good scope for future prospects. People of such countries are like these products and used it.

Figure 14 explained that Kolkata sea contributed largest port area, where $87.7 \%$ of total exports of Jute shopping Bags in India followed by Nhavashava sea contribution was $5.4 \%$, Kolkata Air Cargo Contribution was $5.3 \%$ and Delhi Air Cargo was $1.6 \%$ of value of Total export Share in the year 2015-16.

Figure 15 explained that Export of Jute Shopping Bags export was fluctuating. The Export Value Reached in May 2016 of the amount 2353371 USD and in the month of September 2016 to 2184322 USD.

Table.1 Import of Jute Products in India

\begin{tabular}{|c|c|c|c|c|c|c|}
\hline \multirow[t]{2}{*}{$\begin{array}{l}\text { Jute } \\
\text { Products }\end{array}$} & \multicolumn{2}{|c|}{ February 2015} & \multicolumn{2}{|c|}{ February 2016} & \multicolumn{2}{|c|}{$\begin{array}{l}\% \text { increase /decrease } \\
\text { during February } 2016 \text { as } \\
\text { compared to February } \\
2015\end{array}$} \\
\hline & $\begin{array}{l}\text { Quantity } \\
\text { (M.Ton) }\end{array}$ & $\begin{array}{l}\text { Value } \\
\text { Rs/Lakh }\end{array}$ & $\begin{array}{l}\text { Quantity } \\
\text { (M.Ton) }\end{array}$ & $\begin{array}{l}\text { Value } \\
\text { Rs/Lakh }\end{array}$ & Quantity & Value \\
\hline $\begin{array}{l}\text { Total jute } \\
\text { Products }\end{array}$ & 9498 & 4663.00 & 10269 & 7108.00 & $+08 \%$ & $+52 \%$ \\
\hline
\end{tabular}

Source: Office of the Deputy Commissioner of Customs, Petra pole Land Customs Station, Petra pole, 23-parganas (N)

Table.2 Indian Export of All jute Goods to Top 12 Importing country Value wise (2014-15)

\begin{tabular}{|l|l|l|l|l|l|l|l|}
\hline Country & $\begin{array}{l}\text { Value } \\
\text { (Rs/Million) }\end{array}$ & Country & $\begin{array}{l}\text { Value } \\
\text { (Rs/Million) }\end{array}$ & Country & $\begin{array}{l}\text { Value } \\
\text { (Rs/Million) }\end{array}$ & Country & $\begin{array}{l}\text { Value } \\
\text { (Rs/Million) }\end{array}$ \\
\hline USA & 4244.01 & Netherland & 1089.05 & Australia & 582.36 & Belgium & 392.53 \\
\hline UK & 1431.07 & Germany & 941.96 & $\begin{array}{l}\text { Cote } \\
\text { D'ivoire }\end{array}$ & 509.56 & Sudan & 360.75 \\
\hline Ghana & 1292.82 & $\begin{array}{l}\text { Saudi } \\
\text { Arab }\end{array}$ & 898.83 & UarabEmts & 466.53 & Italy & 357.50 \\
\hline
\end{tabular}

Source: DGCI\&S, Kolkata 
Table.3 Export of Jute goods From India Value: Rs/Million

\begin{tabular}{|l|l|l|l|l|l|l|}
\hline Product & $2009-10$ & $2010-11$ & $2011-12$ & $2012-13$ & $2013-14$ & $2014-15$ \\
\hline Hessian & 3184.55 & 7404.74 & 9788.13 & 9032.80 & 8610.25 & 7695.81 \\
\hline Sacking & 1110.04 & 2239.47 & 4189.37 & 4164.73 & 5270.01 & 2965.55 \\
\hline Yarn & 1442.01 & 5309.62 & 2820.14 & 2211.62 & 1435.83 & 1387.35 \\
\hline JDPs & 2308.28 & 2697.48 & 3199.01 & 3635.93 & 4838.76 & 5085.70 \\
\hline
\end{tabular}

Source: DGCI\&S, Kolkata

Table.4 Export of Jute Diversified Products from India: Value: Rs / Million

\begin{tabular}{|l|l|l|l|l|l|}
\hline Products & $2010-11$ & $2011-12$ & $2012-13$ & $2013-14$ & $2014-15$ \\
\hline $\begin{array}{l}\text { Floor } \\
\text { Coverings }\end{array}$ & 1342.36 & 1420.05 & 1789.91 & 2160.99 & 2388.99 \\
\hline $\begin{array}{l}\text { Hand and } \\
\text { Shopping Bags }\end{array}$ & 1264.22 & 1636.61 & 1696.95 & 2448.02 & 2518.42 \\
\hline Wall Hangings & 29.90 & 40.97 & 2.09 & 5.73 & 8.48 \\
\hline Gift Articles & 22.86 & 14.84 & 64.85 & 38.27 & 40.48 \\
\hline $\begin{array}{l}\text { Decorative } \\
\text { Fabrics }\end{array}$ & 28.61 & 86.08 & 79.59 & 184.38 & 123.71 \\
\hline $\begin{array}{l}\text { Total of JDPs } \\
\text { export }\end{array}$ & 2687.95 & 3198.35 & 3633.49 & 4837.39 & 5080.08 \\
\hline
\end{tabular}

\section{Source: DGCI \& S, Kolkata}

Table.5 Exporting Countries of Jute Geotextiles product from India 2015-16

\begin{tabular}{|l|l|l|l|}
\hline S1 Ni & Name of Exporting Countries & $\begin{array}{l}\text { Export Value in USD } \\
2016-17\end{array}$ & $\begin{array}{l}\% \text { of Total } \\
\text { Contribution }\end{array}$ \\
\hline 01 & United States & 1519087 & $97.7 \%$ \\
\hline 02 & Kenya & 19097 & $1.2 \%$ \\
\hline 03 & Australia & 9550 & $0.61 \%$ \\
\hline 04 & China & 6517 & $0.41 \%$ \\
\hline
\end{tabular}

Table.6 Export Value of Jute Shopping Bags by Countries. in the Year 2015-16

\begin{tabular}{|l|l|l|l|l|l|}
\hline Countries & $\begin{array}{l}\text { Export Value } \\
\text { in USD }\end{array}$ & $\begin{array}{l}\text { Percentage of } \\
\text { Total export }\end{array}$ & Countries & $\begin{array}{l}\text { Export Value } \\
\text { in USD }\end{array}$ & $\begin{array}{l}\text { Percentage of } \\
\text { Total export }\end{array}$ \\
\hline $\begin{array}{l}\text { United } \\
\text { Kingdom }\end{array}$ & 31403752 & $47.1 \%$ & Germany & 2794156 & $4.2 \%$ \\
\hline United States & 11801471 & $17.7 \%$ & Netherlands & 2294975 & $3.4 \%$ \\
\hline Australia & 4549998 & $6.8 \%$ & France & 1942344 & $2.9 \%$ \\
\hline Saudi Arabia & 3029905 & $4.5 \%$ & Italy & 1087864 & $1.6 \%$ \\
\hline
\end{tabular}


Fig.1 Export of All Jute Goods to Top 12 Countries in the year 2014-15

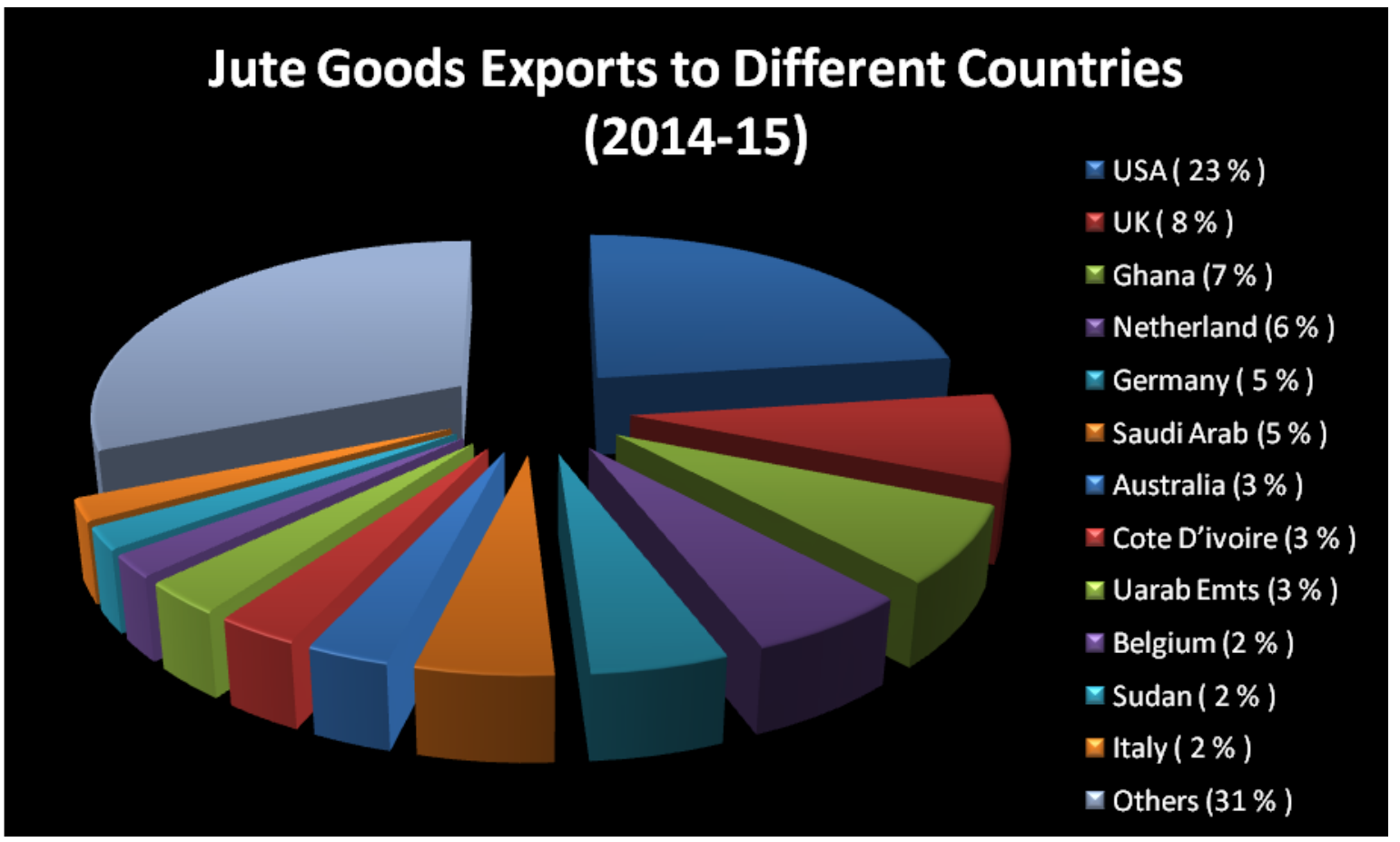

Fig.2 Value in USD of Hessian jute fabric Export from June 2016 to November 2016

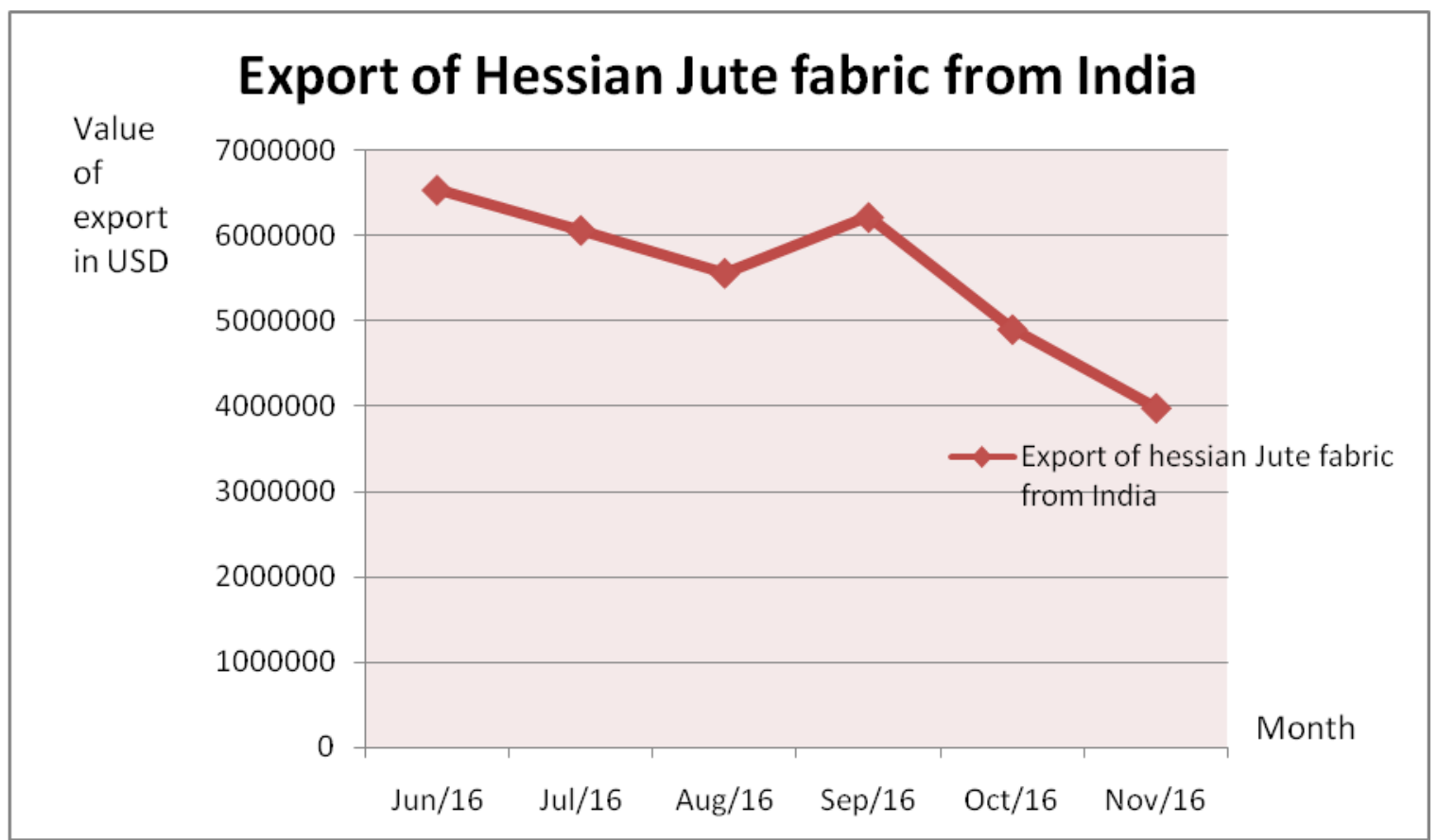


Fig.3 Buyers contribution towards import of hessian cloth from India in the year 2015-16

\section{Buyers Contribution in \% towards Hessian Cloth Export Value in 2015-16}
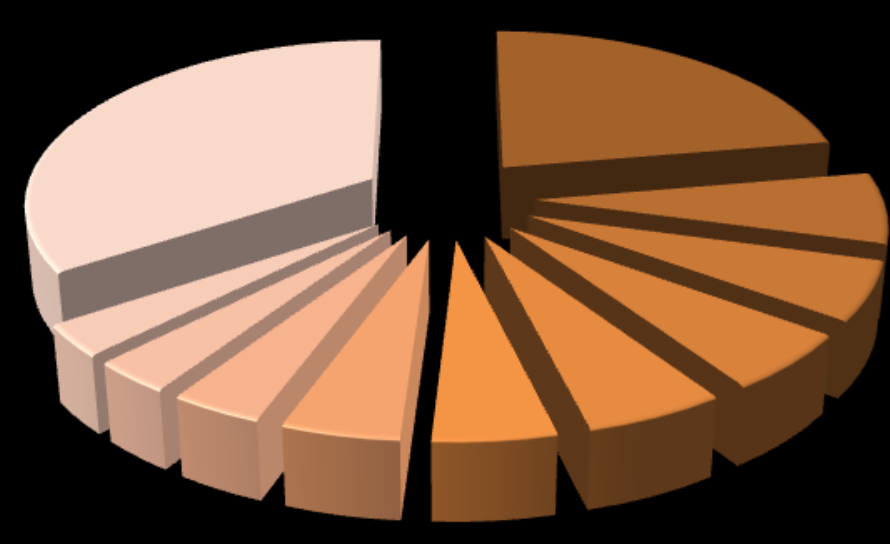

I United States $(22.3 \%)$

× Germany (6.9\%)

ت Saudi Arabia (5.7\%)

nunited kingdom $(5.6 \%)$

Egypt (5.6\%)

n Australia (4.9\%)

M Japan $(4.7 \%)$

E United Arab Emirates (3.7\%)

I Iran $(3.2 \%)$

n Qatar $(3.1 \%)$

n Others $(34.3 \%)$

Fig.4 Value of Hessian cloth export from India in the year 2015-16 by ports (USD)

\section{Distribution of value of Export of Hessian Cloth in USD by leading Port (2015-16)}

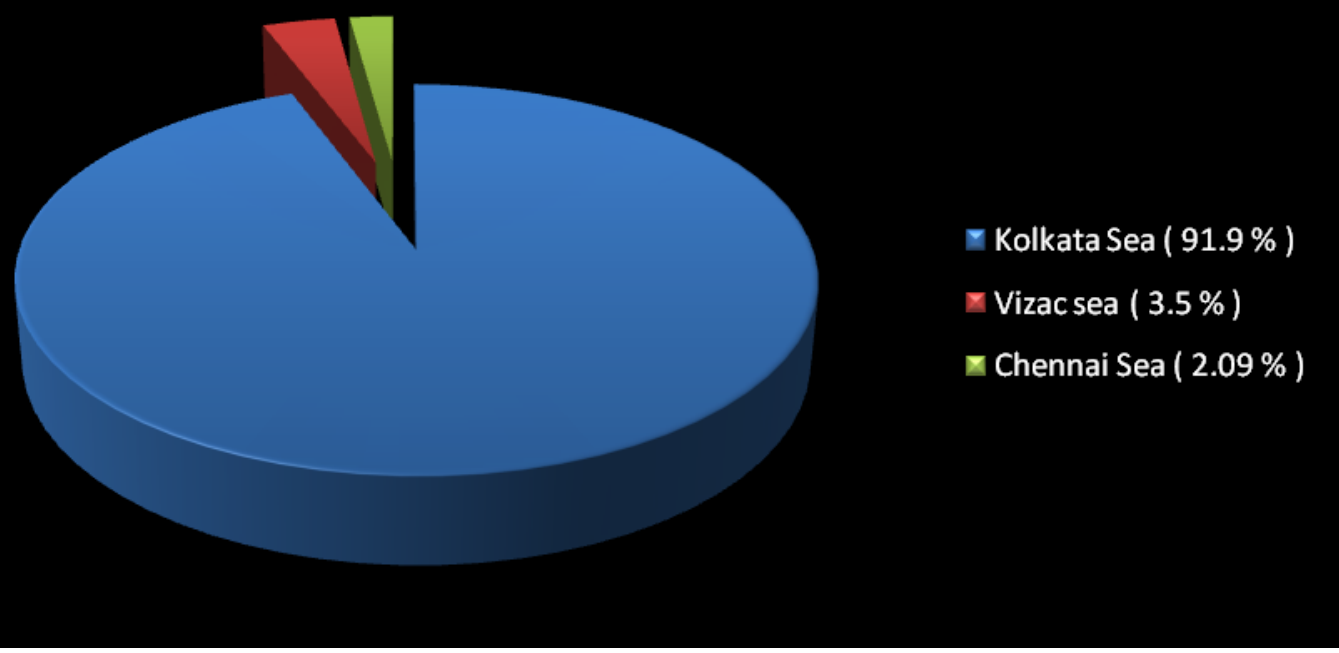


Fig.5 Indian Export of Jute Bags in USD Values

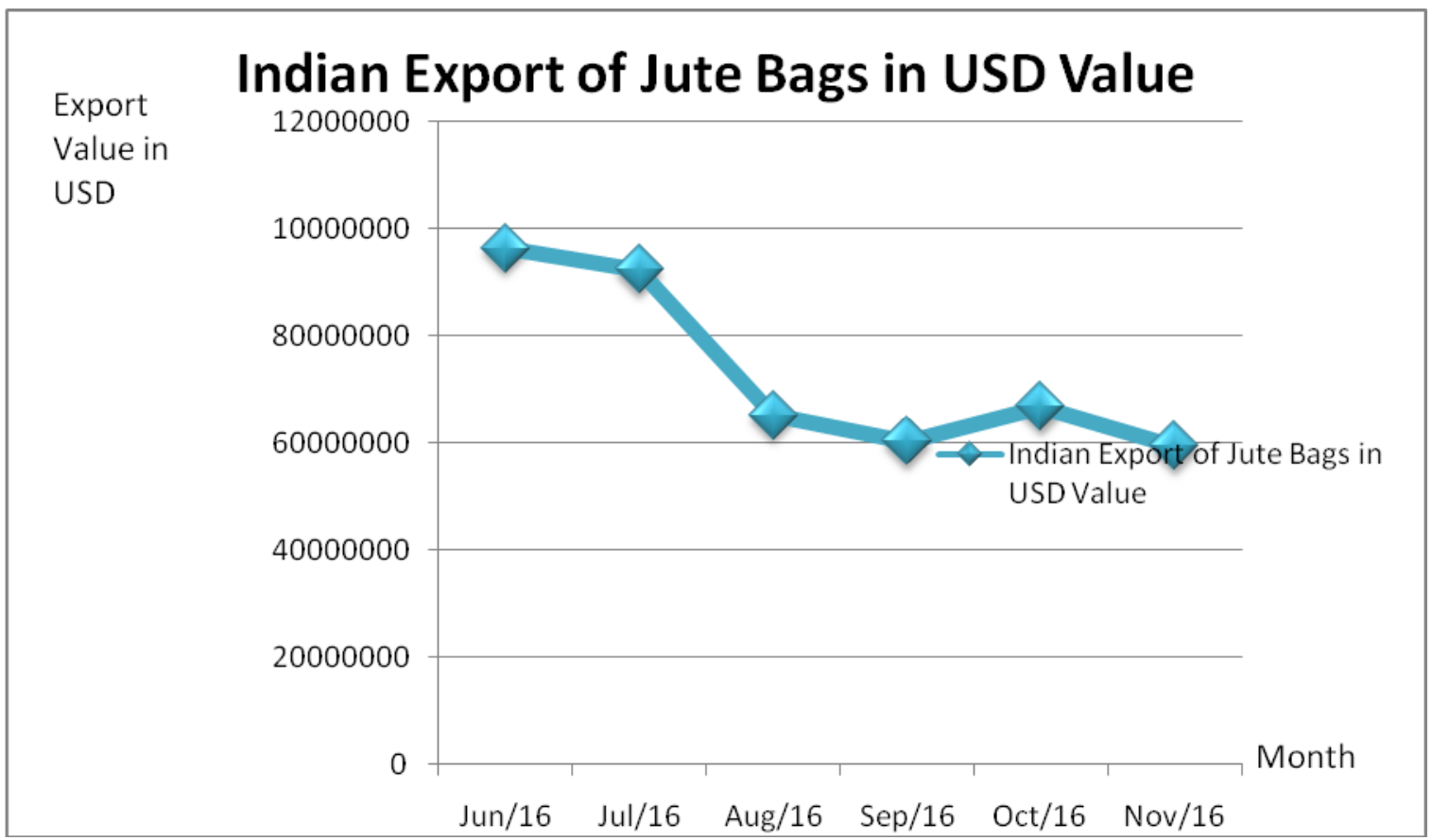

Fig.6 Export Trend of Jute Goods over different years

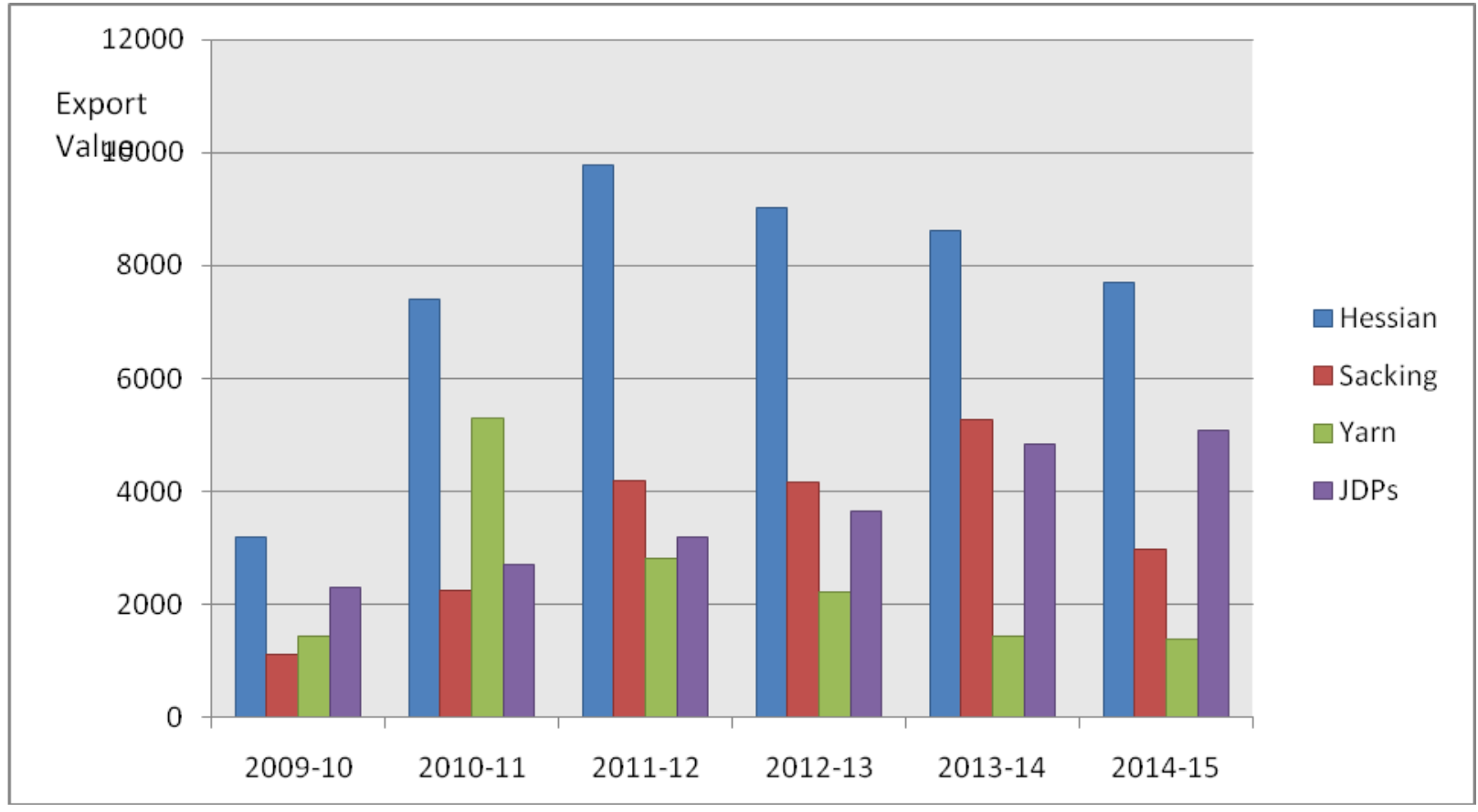


Fig.7 Variation of Export Value of Jute Diversified Products over Different Years

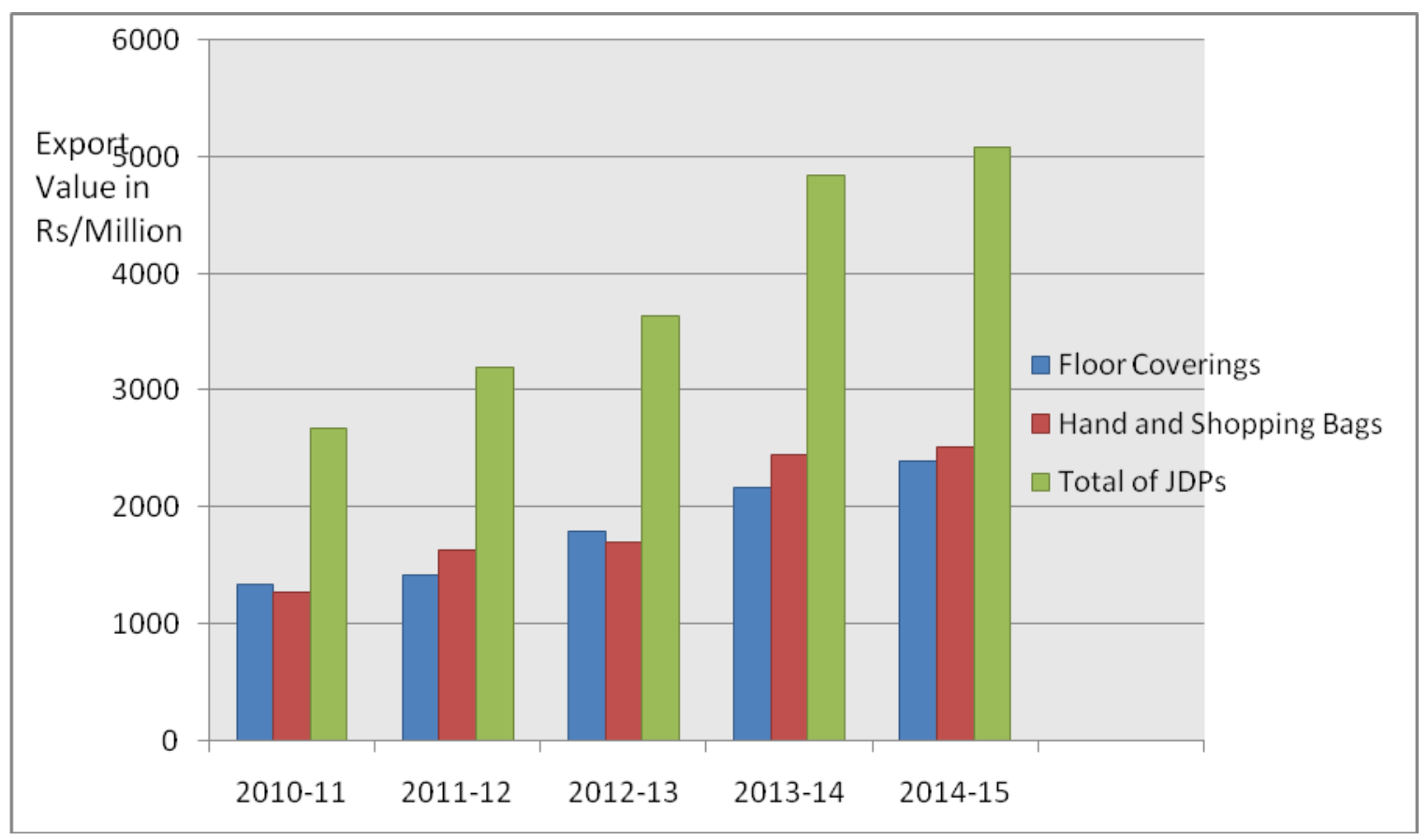

Fig.8 Contributions of Different JDPs towards Export Value

\section{Distribution of Different JDPs over total JDPS Ecport Value of The Year 2014-15}

× Floor Coverings (47\%)

× Hand \& Shopping Bags (49.5\%)

r Wall hangings $(0.18 \%)$

m Gift Articles $(0.79 \%)$

m Decorative Fabrics $(2.43 \%)$ 
Figure.9 Trend of Export values of Laminated Jute Bags from India

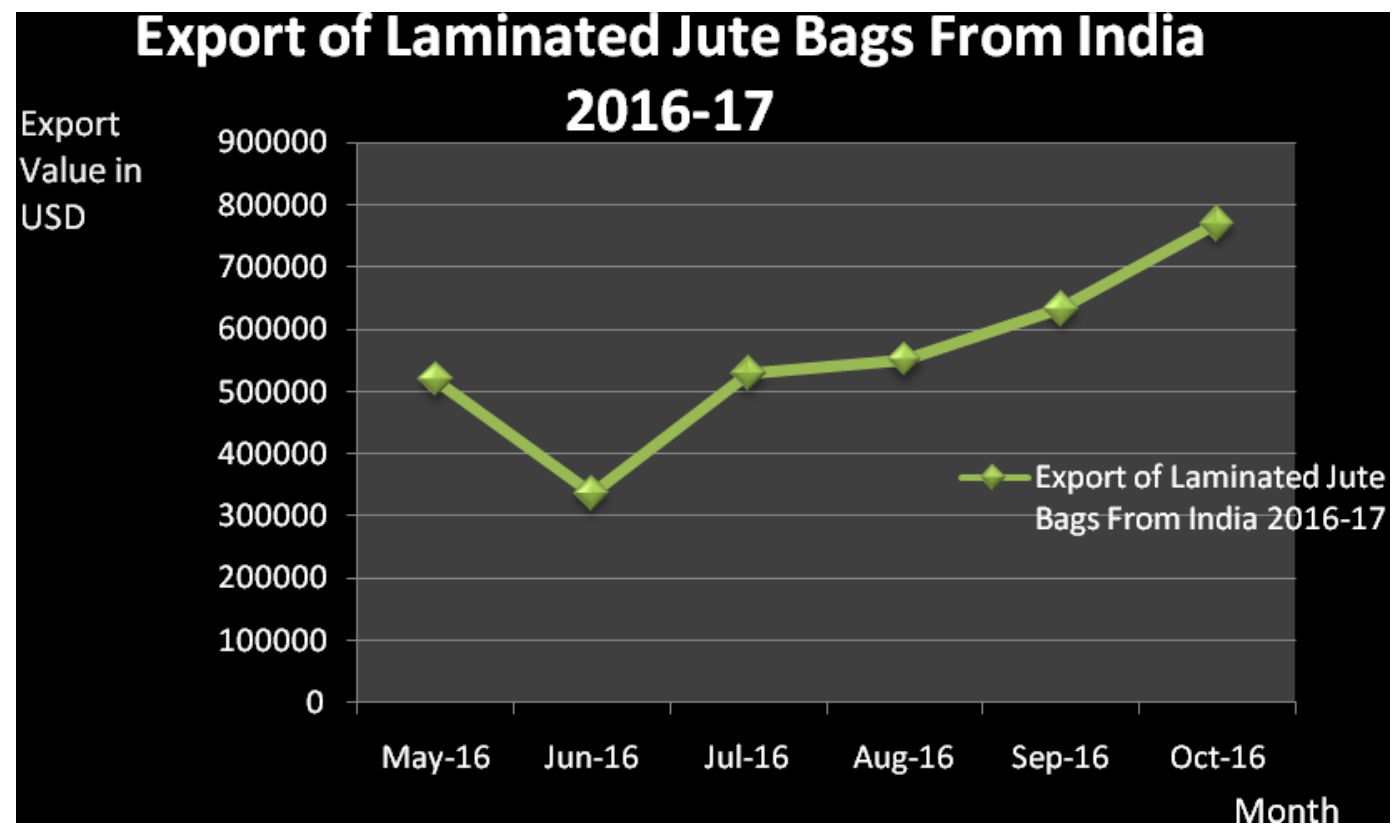

Fig.10 Distribution of Different Ports of India in terms of Value of Export

\section{Major Ports Contribution towards Exports Value of Laminated Jute Bags (2016-17)}

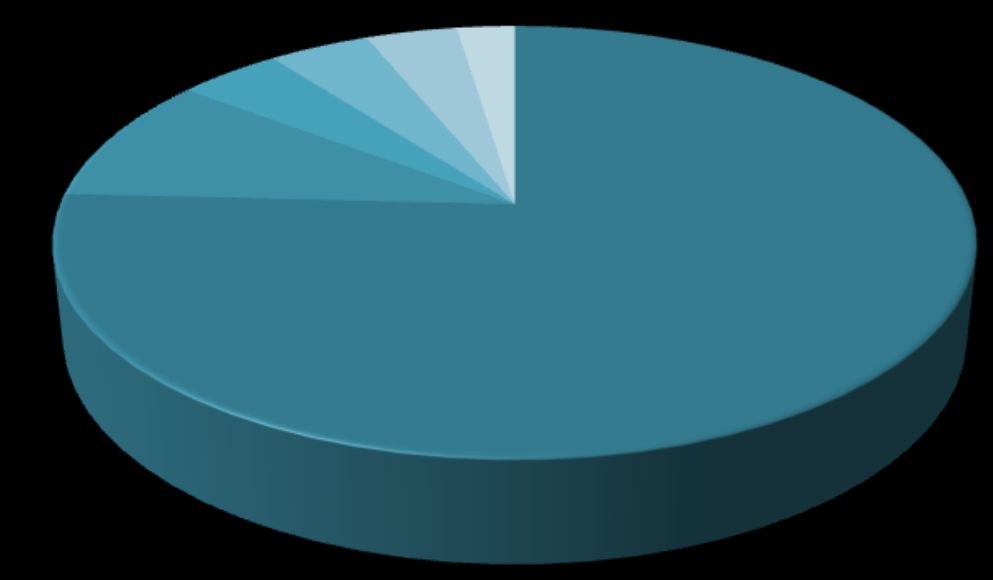

× Kolkata Sea (75.8\%)

I Nihava Shava sea( $9.5 \%$ )

$x$ Pathi ICD $(4.3 \%)$

Molkata Air Cargo (4.2 \%)

E Chennai Sea((3.8\%)

E Channai Air Cargo (2.4\%) 
Fig.11 Variation of Export value of Jute Geotextile from India 2016-17

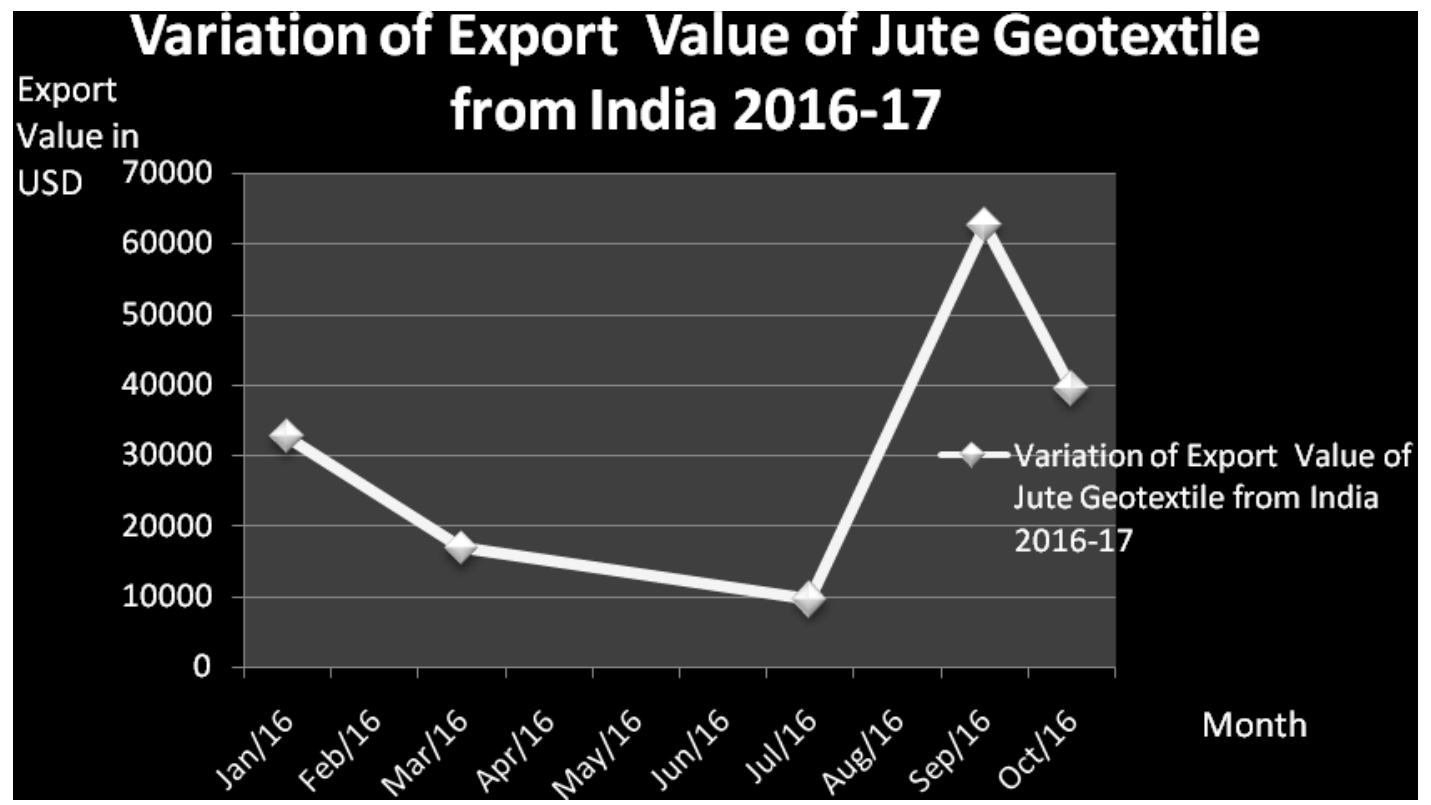

Fig.12 Contribution of Ports towards Exports of Jute Geo Textiles in the year 2015-16

\title{
Ports Contribution towards Export value of Jute Geo Textiles in The year 2015-16
}

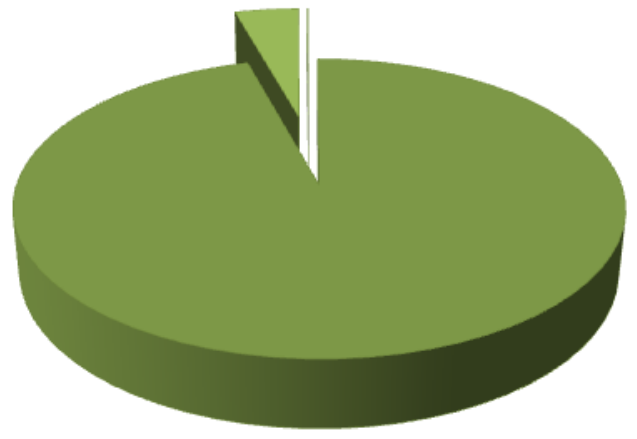

\author{
- Kolkata Sea $(95.7 \%)$ \\ $\square$ Coachin Sea $(4.2 \%)$ \\ $\square$ Kolkata Air cargo $(0.1 \%)$
}




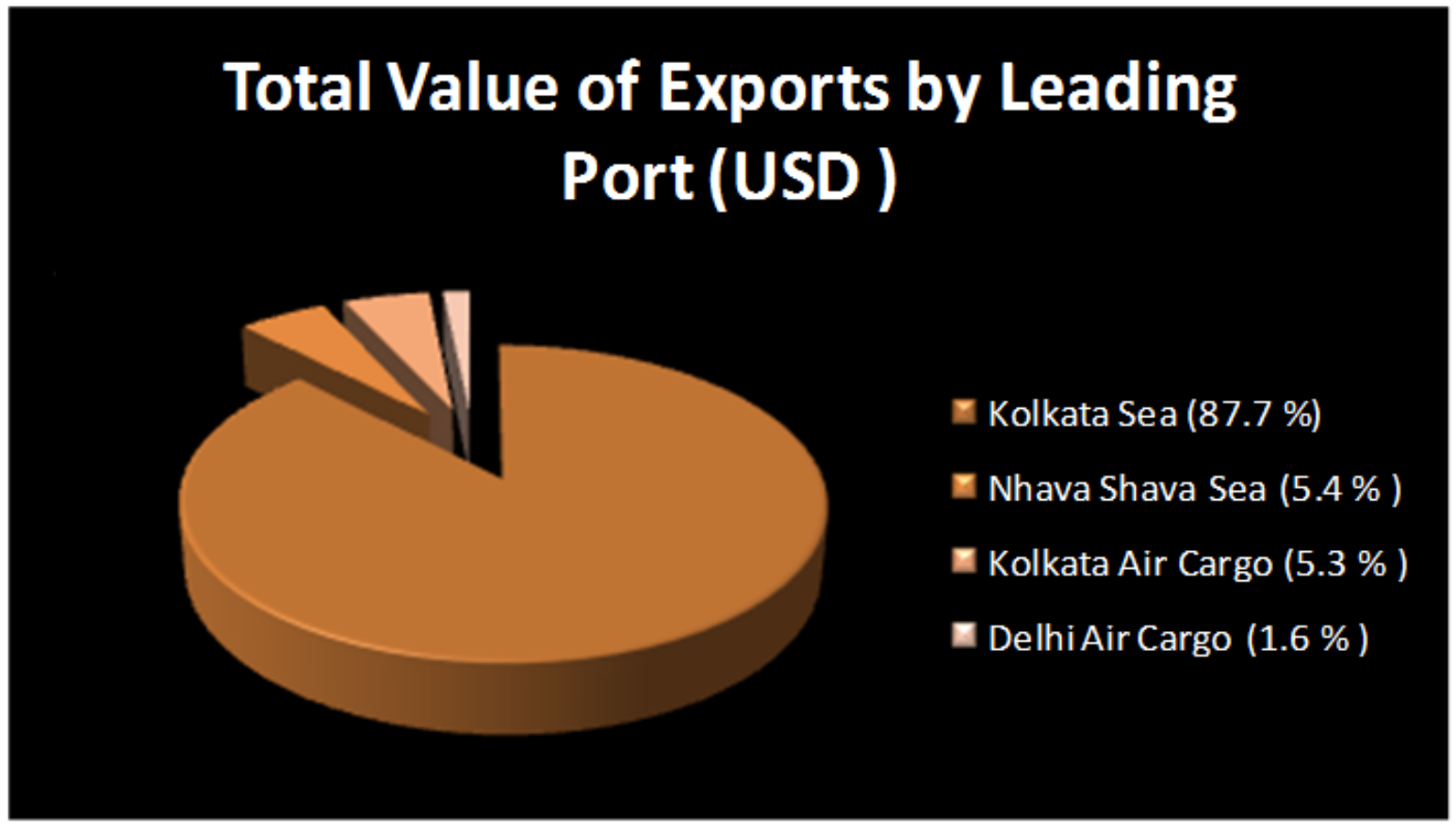

Fig.14 Monthly Export Value in USD of Indian Jute Shopping Bags

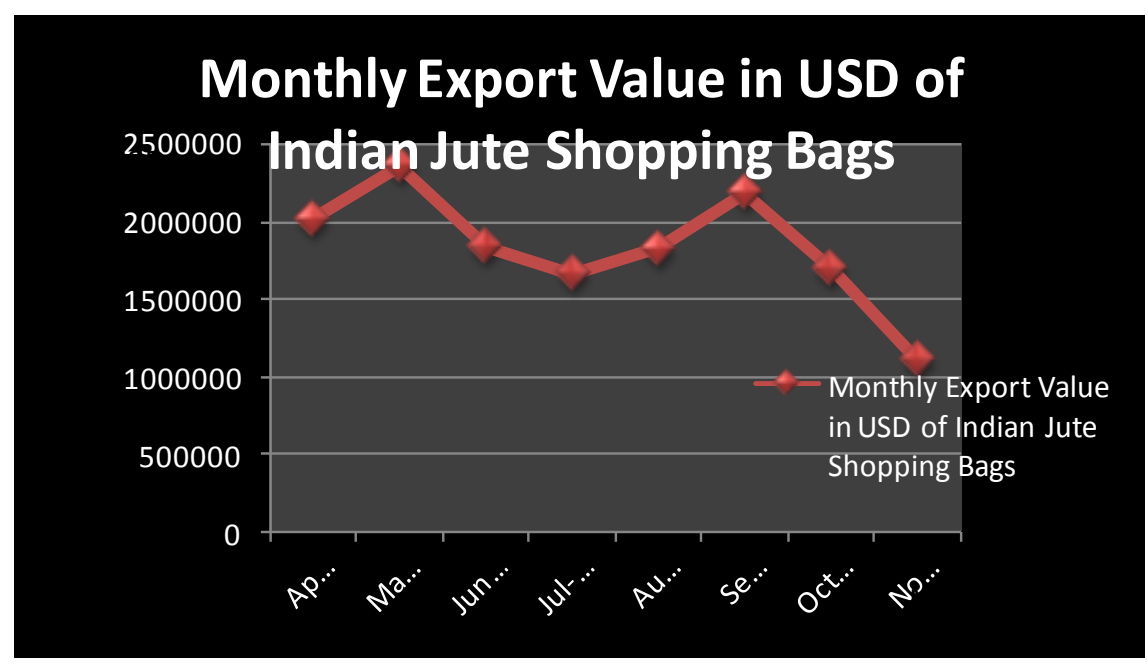

Government Initiatives for Further Improvement of Foreign Trade

Following steps are taken for further Development of Foreign Trade of Indian Jute Goods

- Restructure Jute Corporation of India to enhance its efficiency and capacity to handle huge quantity of Jute to be procured from growers in the country. The restructuring plan includes outsourcing of Department Purchase Centre (DPC) activities, rationalization of manpower and merger / closer of unviable DPCs.
- Union Textile Ministry had formed Standing Advisory Committee (SAC) for monitoring and control of reservation for the jute sector through the packaging order.SAC also recommended to the import of jute bags and fabric from Nepal and Bangladesh.SAC was formed to protect the traditional jute sector against alternative modes of packaging such as synthetic HDPE bags. Sacking accounted for around 65 percent of jute usage and initially food grains, fertilizer and sugar were reserved for jute packing. 
- The new five year Foreign Trade Policy, 2015-20 provides a framework for increasing exports of goods and services as well as generation of employment and increasing value addition in the country.

- Trade facilitation and enhancing the ease of doing business are the other major focus areas in this new FTP.

- Major Objectives of new FTP is to move towards paperless working in $24 * 7$ Environment.

- Government has reduced the number of mandatory documents required for export and imports to three. The Approved Exporter System will help the manufacturer exporters considerably in getting fast access to International Markets.

- In the new policy FTP 2015-16, two new Schemes, Merchandise Exports from India Scheme (MEIS) and Service Exports from India Scheme (SEIS) were introduced.

- For encouraging manufacturing and exports, a number of steps have been introduced. They are a fast track clearance facility for these units, permitting them to share infrastructure facilities, permitting inter unit transfer of goods and services, permitting them to set up warehouse near the port of export and to use duty free equipment for training purposes.

- Indian Jute Industries Research Association (IJIRA) and Surveillance General Superintendent (SGS) India Ltd are jointly engaged in food grade Jute Products Certification. Certified Indian food grade Jute products carry a logo as a mark of quality.

\section{Conclusion}

The Indian Jute sector comprises organized Jute industry as well as a large number of tiny cottage units. Both the areas are now engaged to produce Jute goods high quality Fabrics with exotic colors and design Jute goods.
It is found that after blending with other natural and synthetic fibres the final product ensures total consumer satisfaction in terms of lectures, and aesthetic appeal. It is proved that Jute products have good export potential in national and International markets. National Centre for Jute Diversification is a nodal agency for promotion of jute diversification through commersiliasation of technologies. NCJD operates various schemes to assist entrepreneurs, craft persons, artisans, buyers and NGOs in order to promote Jute and Jute diversified activities. Jute diversified activities are also promoted by IJIRA, Jute manufactures Development Council, IJMA and other R \& D Institutes.

\section{References}

Rahima, A. 2015. 21 Jute Goods Exports to Australia: An Analysis of Market Potentials for Bangladeshi Jute Products', Int. J. Management \& Business Studies, Vol 5, issue 2, www.ijmbs.com.

Md. Mohluddin. 2015. "Green Marketing of Jute and Jute Products, J. Business and Manage., vol 17, issue 2, ver 1, pp 52-57, www.josrjournals.org.

www.planetexim.net.

www.dir.indiamart.com.

www.worldjute.com.

www.jutehandicrafts.com.

www.craftsvilla.com.

www.jutecottage.in.

www.jutepalace.in.

www.jute.com.

www.data.gov.in.

Ijma.org

www.ijira.org.

www.jute.com

www.zauba.com.

www.infodriveindia.com.

www.intracen.org.

www.exportimportstatistics.com.

www.epch.in.

www.essay.utwente.nl.

www.exportgenius.in.

\section{How to cite this article:}

Satya Narayan Bag. 2017. Indian Foreign Trade on Natural Cellulosic Jute Fibre Products. Int.J.Curr.Res.Aca.Rev. 5(4), 36-48. doi: https://doi.org/10.20546/ijcrar.2017.504.007 